\title{
Quantitative effects of volunteer plants on gluco- sinolate content in double-low rapeseed (Brassica napus L.) : a theoretical approach
}

\author{
Wulf DIEPENBROCK, Jens LÉON \\ Institute of Crop Science and Plant Breeding, University of Kiel, Olshausenstraße 40, D-2300 Kiel (Germany, F.R.)
}

\begin{abstract}
Assessment of glucosinolate (GSL) content in rapeseed is important because degradation products of glucosinolates are the most limiting factors for use of rapeseed meal, the most concentrated vegetable protein feed produced in cool temperate climates. Volunteer plants with about $90 \mu$ mole GSL/g seed can increase glucosinolate content in new quality stands. This effect is especially relevant when rapeseed is a major component in crop rotation and also during seed multiplication. The goal of the present study was to estimate quantitatively the effects of volunteer plants (VPs) in new quality stands on GSL-content of rapeseed. It was shown that a content of about $10 \mu \mathrm{mole} / \mathrm{g}$ seed in commercial seeds is necessary in order not to exceed $20 \mu$ mole/g seed coming from VPs. Generally, seed multiplication will only be successful when the GSL content is significantly below $20 \mu \mathrm{mole} / \mathrm{g}$ seed at the third step of multiplication. From the calculated data it appeared that the steady immigration of more than two percent of VPs with high GSL-content during seed multiplication would be unacceptable to seed producers.
\end{abstract}

Additional key words : Seed multiplication.

\section{INTRODUCTION}

In Cruciferae the genera Brassica and Raphanus provide species cultivated as vegetables, oil-seed crops and forage crops. Rapeseed (Brassica napus L.) with about $40 \%$ oil and $25 \%$ protein is adapted to nearly all major parts of the world. Today's interest in rapeseed production centers on the seed as a source of edible oil and valuable protein.

Oil-free rapeseed meal represents the most concentrated vegetable protein feed produced in the cool temperate climate. The lysine content is only slightly lower than that in soya meal whereas the contents of methio- nine and cystine are higher in rapeseed meal (Huss, 1972). The most limiting factors for the use of rapeseed meal are the degradation products of glucosinolates. However, breeding of so-called double-low rapeseed has been successful. Seeds of the new varieties are low both in glucosinolate and erucic acid content. The first double-low varieties were poor-yielding but, more recently winter varieties have reached equal or superior seed yield to the best low erucic acid varieties, speeding the conversion to double-low quality in Western Europe.

In spite of this significant progress in breeding, introduction of new varieties may still be subjected to 


$\begin{aligned} & \begin{array}{c}\text { mode of } \\ \text { pollination } \\ \text { frequency }\end{array} \\ & \text { gengtypes }\end{aligned}$
$\begin{aligned} & \text { frequency } \\ & \text { pollination }\end{aligned}$

Figure 1

Phenotypic frequencies in $M_{2}$. Frequences phénotypiques en $\mathrm{M}_{2}$ (GSL, gsl = glucosinolates.) ( $G S L, g s l=$ glucosinolates.)

problems during seed production. Inheritance of glucosinolate content is more complex than that of erucic acid and the concentration of glucosinolate compounds cannot be reduced to zero. Volunteer plants with about $90 \mu$ moles GSL/g seed growing in new quality stands of double-low cultivars may increase glucosinolate content during seed multiplication (LÉON \& DiEPENBROCK, 1985). This effect will be strengthened at high proportions of single-low rapeseed in crop rotations.

The present paper offers a theoretical approach to calculation of the effects of volunteer plants in new quality stands on GSL-content of rapeseed, with special reference to seed multiplication.

\section{METHODS}

The mode of GSL-inheritance is an important issue when estimating the effects of volunteer plants (VPs) possessing high GSL-contents over several steps of multiplication. It is generally agreed that seed GSLcontent is determined by maternal plant genotype (MøLler et al., 1985). Genetic studies have indicated existence of several (3-5) gene loci of which the recessive alleles condition the low GSL trait (BusCH \& RöBBELEN, 1981). Overdominance of a high content has been reported for both glucobrassicanapin (KONDRA \& Stefansson, 1970) and total GSLs (Gland, 1985). However, understanding of gene action controlling glucosinolate levels is not yet complete.

A model is described here which includes several gene loci controlling total GSL-content. Due to a simplification described later, knowledge of the exact number of gene loci is not a necessary prerequisite. It is postulated that each locus shows complete dominance for the allele controlling high GSL-content and that the loci interact (epistasis). On the basis of this simplification only genotypes possessing recessive alleles on all loci reveal low GSL-contents.

Rapeseed is self-pollinating and cross-pollinating simultaneously. Therefore, during the first step of multiplication (M), immigrated VPs will cross onto the population. Within the following multiplications, additional VPs will also cross onto the genotypes of the original population. The $F_{1}$ are partly selfed, producing $\mathrm{F}_{2}$, and partly crossed onto both parents, producing backcrosses (BC). Because GSL-content is determined maternally, plants of the original multiplied population will have a low seed GSL-content. Starting from the next multiplication, a proportion of the seeds produced by $\mathrm{F}_{2}$ - and $\mathrm{BC}$-plants will have low GSL-contents. To characterize this particular group of plants deriving from crosses of VPs and the original population, more information about numbers of gene loci would be essential. As no details are available these plants are ignored. So, from the first step of multiplication onwards the GSL-content becomes insignificantly overestimated. It is further assumed that all plants possess the same fitness.

Underlying this model it is necessary to estimate the frequency of plants producing low total GSL-content. Therefore, information on self-pollination rate is only necessary for plants with low GSL-content.

Let $\mathrm{a}_{\mathrm{i}}$ be the number of plants $/ \mathrm{m}^{2}$ including VPs in year $i$ and $y_{i}$ the number of $V P s / m^{2}$ in year $i$. The estimate of the GSL-content of the first multiplication is :

$$
\mathbf{M}_{1}=\frac{\mathrm{a}_{1}-\mathrm{y}_{1}}{\mathrm{a}_{1}} \mathrm{~b}_{1}+\frac{\mathrm{y}_{1}}{\mathrm{a}_{1}} \mathbf{c}_{1}
$$


where $b_{i}$ is the GSL-content of the population to be multiplied in year $i$ and $c_{i}$ is the GSL-content of the VPS and their descendants in year $i$.

Let $\alpha_{1}=\left(a_{1}-y_{1}\right) / a_{1}, M_{2}, M_{3}$ and $M_{4}$ estimate the GSL-content of respectively the second, the third and the fourth step of multiplication :

$$
\begin{aligned}
M_{2}= & \alpha_{2} b_{2}+\left(1-\alpha_{2}\right) c_{2} \\
& \alpha_{2}=\left(s_{1} \alpha_{1}+\left(1-s_{1}\right) \alpha_{1}{ }^{2}\right)\left(a_{2}-y_{2}\right) / a_{2} \\
M_{3}= & \alpha_{3} b_{3}+\left(1-\alpha_{3}\right) c_{3} \\
& \alpha_{3}=\left(s_{2} \alpha_{2}+\left(1-s_{2}\right) \alpha_{2}{ }^{2}\right)\left(a_{3}-y_{3}\right) / a_{3} \\
M_{4}= & \alpha_{4} b_{4}+\left(1-\alpha_{4}\right) c_{4} \\
& \alpha_{4}=\left(s_{3} \alpha_{3}+\left(1-s_{3}\right) \alpha_{3}{ }^{2}\right)\left(a_{4}-y_{4}\right) / a_{4}
\end{aligned}
$$

where $s_{i}$ is the proportion of self-pollination in year $i$.

In order to provide a better understanding of the formulas, a developmental scheme for phenotypic frequencies in $\mathbf{M}_{2}$ is given as an example in figure 1 .

\section{RESULTS}

Figure 2 shows the effect of the number of VPs $/ \mathrm{m}^{2}$ on seed glucosinolate (GSL) content during four steps of multiplication. It was assumed that seeds of the sown crop (controlled population) contained $10 \mu$ mole GSL/g seed and that crop density reached 60 plants $/ \mathrm{m}^{2}$, VPs ( $90 \mu$ mole GSL/g seed) included. The selfing rate was considered to be $70 \%$. In any case, one $\mathrm{VP} / \mathrm{m}^{2}$ led to values below $20 \mu$ mole GSL but adding further VPs resulted in GSL-contents increasing progressively. Within the first multiplication the presence of even six VPs was calculated not to exceed $20 \mu$ mole but finally, $35 \mu$ mole were surpassed when four or more VPs occurred during multiplication.

Five VPs growing in a population with $15 \mu$ mole already caused more than $20 \mu$ mole GSL in the first generation (fig. 3). This level was, throughout, reached or exceeded at the third step of multiplication, and within a further generation four to six VPs resulted in GSL-contents above the $35 \mu$ mole limit. GSL-contents influenced by one to three VPs did not exceed $35 \mu$ mole GSL in any case. Although the basic GSL-content amounted to $15 \mu$ mole, the increase during multiplication was not as high as calculated for $10 \mu$ mole in the initial population (compare fig. 2).

This trend was also true for basic GSL-content of $30 \mu$ mole (fig. 4). In that case, the overall increase of GSL-contents grew rather moderately, e.g. seeds from the first generation did not exceed $35 \mu$ mole GSL even at five VPs $/ \mathrm{m}^{2}$. The $35 \mu$ mole limit was reached only when six VPs occurred at the first step or when three VPs occurred at the second step of multiplication. However, this level was generally exceeded within the fourth multiplication.

\section{DISCUSSION}

Glucosinolates (GSL) are the main compounds causing nutritional and toxic problems when using rapeseed meal in human food and animal feed. These deleterious factors occupy a rather high portion of the fat-free substance in cruciferous seeds : about $3 \%$ in Brassica campestris, $5-7 \%$ in Brassica napus, about

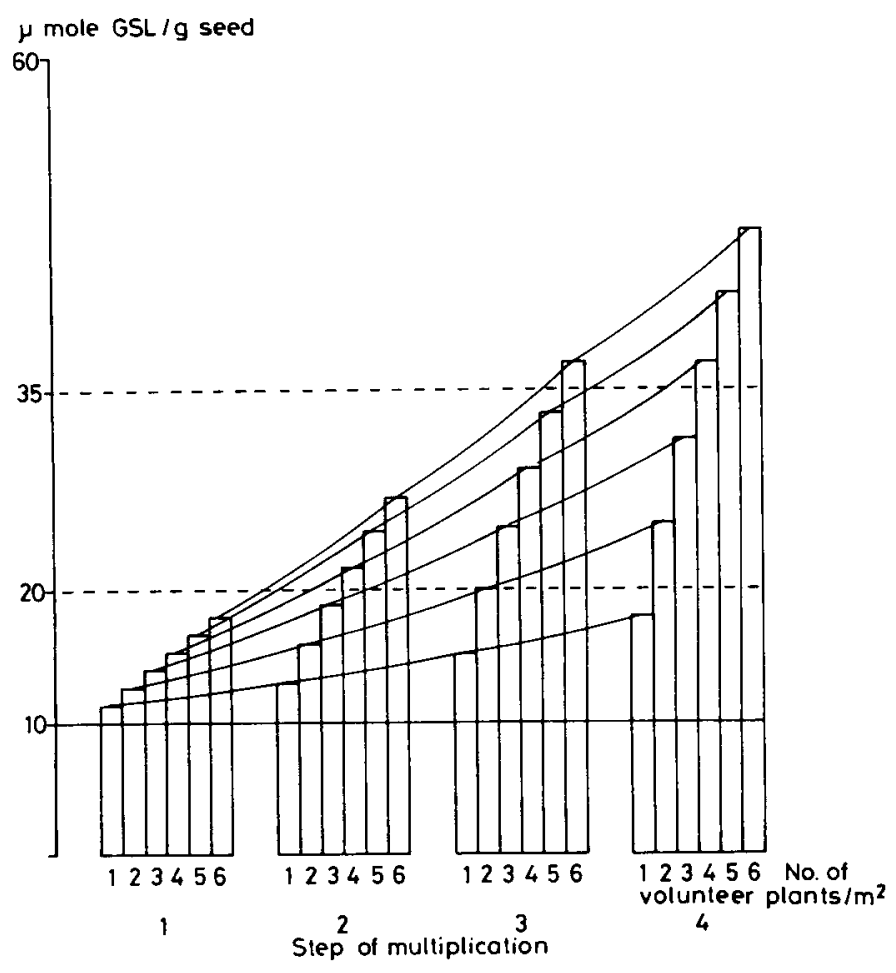

Figure 2

Effect of volunteer plants on seed glucosinolate content ( $\mu$ mole GSL/g seed) during four steps of multiplication.

$\left(60\right.$ plants $/ \mathrm{m}^{2}$, volunteer plants $=90$ umole $G S L ;$ initial population $=$ 10 pmole GSL.)

Effet des repousses sur la teneur en glucosinolates (umole GSL/g de graines) au cours de quatre générations de multiplication.

$\left(60\right.$ plantes $/ m^{2}$, repousses $=90$ umole GSL; population initiale $=$ IO umole GSL.)

8-10\% in Crambe abyssinica, and $9 \%$ in Sinapis alba (APPELQVist, 1971).

The upper limit of GSL-content in double-low varieties of rapeseed is often fixed at $20 \mu$ mole $/ \mathrm{g}$ seed. However, in particular cases, varieties containing between 20 and $35 \mu$ mole GSL/g were also classified as double-low quality types. Therefore, the present data are, throughout, related to both limits.

Rapeseed meal can be used as the only supplementary protein source in barley-based diets for pigs if total GSL-concentration is below $3 \mu \mathrm{mole} / \mathrm{g}$ (EGGUM et al., 1985). Higher GSL-contents, however, may indicate to what extent rapeseed meal should be used in dietetic mixtures of protein concentrates. For example, rapeseed meal from cv. Erglu with a total GSL-content of about $12 \mu \mathrm{mole} / \mathrm{g}$ is not qualified to replace more than $50 \%$ of the supplementary protein in cereal-based diets for growing-finishing pigs (EGGUM et al., 1985). As a consequence, aiming at a significant increase of the portion of rapeseed meal in a diet, the $20 \mu \mathrm{mole} / \mathrm{g}$ limit seems much more suitable as compared to $35 \mu$ mole $/ \mathrm{g}$.

The conversion of double-low varieties to practical application has been retarded by a lack of both reliable methods for GSL determination, and experience with large-scale field trials. Analytical methods often suffered from a lack of sensitivity and precision (OLSEN \& Sørensen, 1983). On the other hand, BAudisch (1984) stressed the relevance of experimental data to the introduction of legislative regulations, especially with 


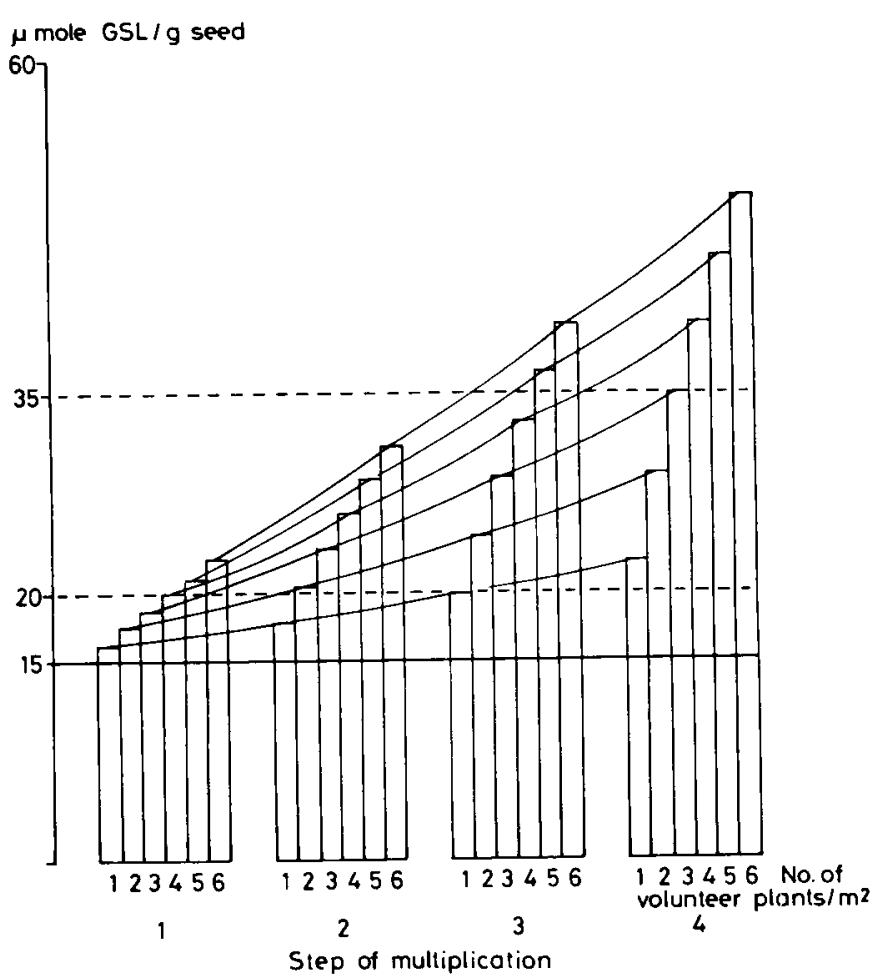

Figure 3

Effect of volunteer plants on seed glucosinolate content (umole GSL/g seed) during four steps of multiplication.

$\left(60\right.$ plants $/ \mathrm{m}^{2}$, volunteer plants $=90$ pmole $G S L ;$ initial population $=$ 15 umole $G S L$.)

Effet des repousses sur la teneur en glucosinolates (umole GSL/g de graines) au cours de quatre générations de multiplication.

$\left(60\right.$ plantes $/ m^{2}$, repousses $=90$ unole $G S L:$ population initial' $=$ 15 umole GSL.)

regard to seed multiplication. As no data are available which are representative of practical application, our own calculations are helpful for modelling the effects of VPs on total GSL-content in rapeseed. As a slight restriction BUSCH \& RÖBBELEN (1981) reported that about $0.24 \%$ of an $\mathrm{F}_{2}$ were homozygous for all recessive alleles controlling the low GSL-content. However, as the proportion of $F_{2}$ is considered to be rather low at the end of multiplication, the simplification of ignoring all low-GSL plants derived from crosses, should result in an insignificant overestimation (compare II. Methods).

With regard to practical implications, the present results refer to a constant degree of self-pollination $(\mathrm{s}=0.7)$ and to a plant density of $60 \mathrm{plants} / \mathrm{m}^{2}$. VPs included (for review see BECKER, 1987; SIERTS et al., 1987). It should be noted that the calculated values can also be generalized directly on a percentage basis, e.g. a density of six VPs $/ \mathrm{m}^{2}$ means $10 \%$ of the whole stand. Consequently, these data are valid for transfer to models including varying plant densities.

It is clearly shown that, in the presence of three $\mathrm{VPs} / \mathrm{m}^{2}$, a content of $10 \mu$ mole in the sown crop is necessary not to exceed $20 \mu$ mole within the first multiplication. Remarkably, the values of the first multiplication are determined by the GSL-content of seeds from VPs because inheritance of GSL is governed by maternal influences (LEIN, 1972; BUSCH \& RÖBBELEN, 1981). Hence, crosses between double-low and singlelow plants with new and traditional quality would only be expressed by the phenotype of $F_{2}$ (second step of

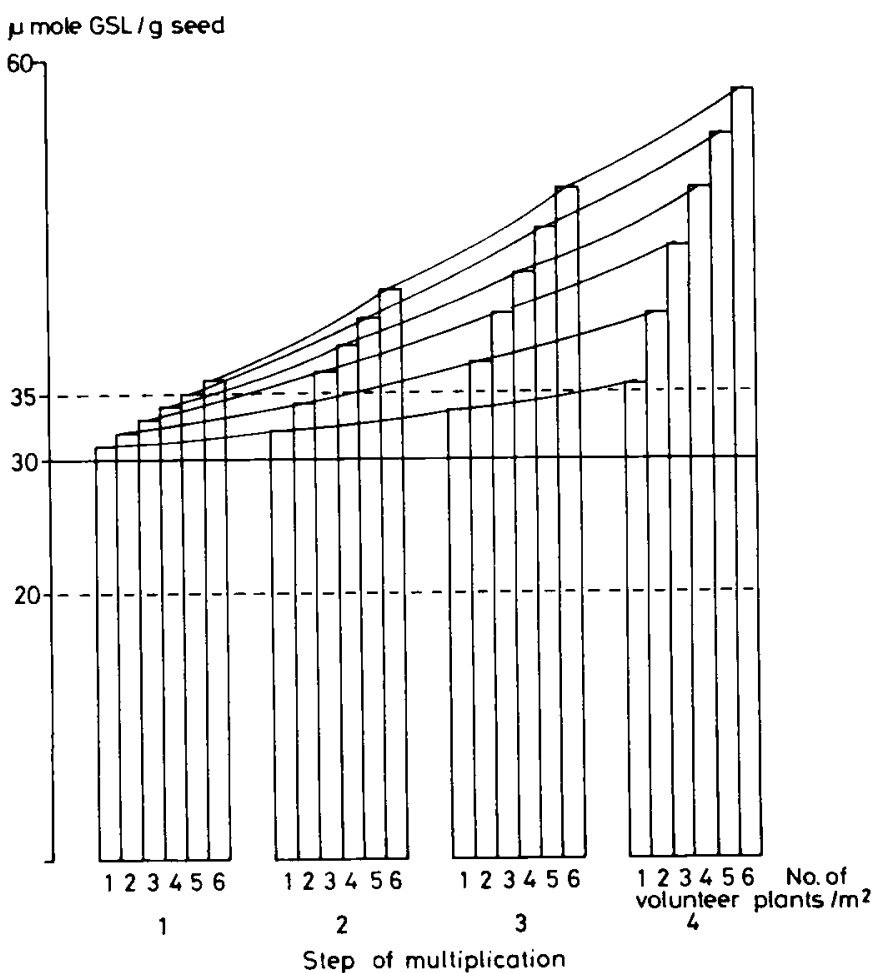

Figure 4

Effect of volunteer plants on seed glucosinolate content ( $\mu$ mole GSL/g seed) during four steps of multiplication.

(60) plants $/ \mathrm{m}^{2}$, volunteer plants $=90$ umole $G S L ;$ initial population $=$ 30 pimole GSL.)

Effet de repousses sur la reneur en glucosinolates ( $\mu m$ ole $G S L / g$ de graines) au cours de quatre générations de multiplication.

$\left(60\right.$ plantes $/ \mathrm{m}^{2}$, repousses $=90$ umole $G S L ;$ population initiale = 30 umole GSL.)

multiplication). This would only raise objections as to seed multiplication, but not to rapeseed cropping.

From the present calculations it becomes obvious that commercial seeds should be limited to a rather low GSL-content (e.g. $10 \mu$ mole) because higher initial contents would rapidly exceed the $20 \mu$ mole limit as influenced by single-low VPs. Furthermore, seed multiplication will be of acceptable quality only when the GSL-content is significantly below that limit in the third generation. So, from the model presented, it appeared that the steady immigration of more than one VP during multiplication cannot be tolerated by seed producers.

In order to relieve rotation systems including high portions of rapeseed, green manuring with rapeseed should also be performed with double-low varieties because seeds which do not germinate within the first growing season are maintained during crop rotation. As a rule, if climatic or working conditions are unfavourable to seed germination, double-low quality should be employed in time to reduce the number of viable seeds of traditional quality in cropping systems.

Finally, it should be pointed out that the estimate of the effects of VPs on the seed GSL-content of doublelow stands given by this model is applicable to a wide spread area of variable field conditions, e.g. plant densities, numbers of VPs, proportions of selfpollination within a given environment or environmental effects on GSL-contents. 


\section{REFERENCES}

Appelqvist L.-A., 1971. Composition of seeds of cruciferous oil crops. J. Am. Oil Chem. Soc., 48, 851-859.

Baudisch H., 1984. Zur Einführung von DoppelNull-Winterrapssorten. Raps, 3 (2), 134-135.

Becker H. C., 1987. Quantitative Genetik und Zuchtmethodik bei Raps - Versuch einer Literaturübersicht. In: Bericht ïber die Arheitstatung der Saatzuchtleiter in Gumpenstein, Verlag der Bundesanstalt für alpenländische Landwirtschaft, Gumpenstein, Österreich, in press.

Busch H., Röbbelen G., 1981. Niedriger Glucosinolatgehalt als Zuchtziel für Winterraps. Angew. Bot., 55, 361-371.

Eggum B. O., Just A., Sørensen H., 1985. Double low rapeseed meal in diets to growing-finishing pigs. In : H. Sørensen (Ed.), Advances in the production and utilization of cruciferous crops. Martinus Nijhoff/Dr. W. Junk Publishers, Dordrecht/Boston/Lancaster, 167 176.

Gland A., 1985. Inheritance of content and pattern of glucosinolate in combinations of resynthesized rapeseed $x$ rapeseed cultures. In: H. Sørensen (Ed.), Advances in the production and utilization of cruciferous crops. Martinus Nijhoff/Dr. W. Junk Publishers, Dordrecht/Boston/Lancaster, 278-285.

Huss W., 1972. Ölkuchen und Rapsschrot in der Tierernährung. Fette, Seif., Anstr. mitt., 74, 634-638.
Kondra Z.. P., Stefansson B. R., 1970. Inheritance of the major glucosinolates of rapeseed (Brassica napus) meal. Can. J. Plant Sci., 50, 643-647.

Lein K. A., 1972. Genetische und physiologische Untersuchungen zur Bildung von Glucosinolaten in Rapssamen. I. Zur Vererbung der Glucosinolatarmut. Z. Pfl. zücht., 67, 243-256.

Léon J., Diepenbrock W., 1985. Fremdaufwuchs als Problem der Qualitätsrapserzeugung. Bayer. Landw. Jahrb., 62, 246-249.

Moller P., Rahman M. H., Stolen O., Sorensen H., 1985. Heredity of fatty acids and glucosinolates in oilseed rape. Possibilities for improvement of rape adapted for the growth conditions in tropical Asia. In : $\mathrm{H}$. Sørensen (Ed.), Advances in the production and utilization of cruciferous crops. Martinus Nijhoff/Dr. W. Junk Publishers, Dordrecht/Boston/Lancaster, 286-300.

Olsen O., Sørensen H., 1983. Glucosinolate analysis. Limitations and possibilities of different producers. Proc. Intern. Rapeseed Conf., Paris, 6, 1356-1361.

Sierts H. P., Geisler G., Léon J., Diepenbrock W., 1987. Stability of yield components from winter oil-seed rape (Brassica napus L.). $J$. Agron. Crop Sci., 158, 107-113. 